\title{
Near Field Radio Frequency Radiation Hazard on Military Armoured Vehicle - Approach to a Dose Assessment
}

\author{
M. R. Jasman'1, S. N. S. Jamaludin ${ }^{1 *}$ and K. M. Yusof ${ }^{2}$ \\ ${ }^{1}$ Faculty of Engineering, DRB Hicom University, 26607 Pekan, Malaysia \\ *Email: rizalriz6960@gmail.com \\ Phone: +6094242400; Fax: +6094242500 \\ ${ }^{2}$ School of Electrical Engineering, Universiti Teknologi Malaysia, 81310 Johor Bahru, \\ Malaysia \\ Phone: +6075533333; Fax: +607556627
}

\begin{abstract}
The level of radio frequency (RF) electromagnetic field emitted from a military armoured vehicle antenna was investigated to identify possible adverse health effect on personnel, especially in the near field region. Both E-Field and H-Field radiations levels emitted from antenna were recorded by emphasising on the main areas of crew working station. To date, open literature on military vehicle and equipment RF radiation hazard safety assessment has limited numbers of discussion especially on RF source distance, location and mode of power transmission. In this investigation, $\mathrm{RF}$ levels from two radio antennas were measured, high frequency (HF) and very high frequency (VHF) with the low and high-power transmission. Measurements were taken in two distinct locations namely; commander and gunner respectively with three different conditions; open hatch, close hatch and open hatch with standing crews which representing the normal and combat situations. The measured E-Field and H-Field levels were then assessed for compliance with occupational reference levels of Military Standard 464C, The Institute of Electrical and Electronics Engineers (IEEE) for Military Workplace standards and International Commission on Non-Ionising Radiation Protection (ICNIRP) guidelines. The occupational standard was exceeded on commander and gunner area at certain condition; nevertheless, the rest of the conditions complied within the occupational standard.
\end{abstract}

Keywords: Military armoured vehicle; high frequency; very high frequency; E-field and $\mathrm{H}$-field; radio frequency radiation.

\section{INTRODUCTION}

The electromagnetic (EM) radiation become hazardous to human health if the exposure received is excessively high. An antenna placed aboard an armoured vehicle with ranging the spectrum of high frequency (HF) and very high frequency (VHF) potentially exposes the crew with radiation hazards respectively with radio frequency (RF) energy. Only a few studies on EM radiation hazards to armoured vehicle crew was found to date.

The danger of radiation hazards occurs due to the RF energy absorbed which transformed into the movement of molecules in the human body. As discussed by the World Health Organisation (WHO), friction between rapidly moving molecules results in temperature rise period. Significant heating may lead to tissues damage if the access heat is dissipated accordingly [1]. A lot of interesting facts have been discovered from open access literature on EM radiation emitted from military radar, antenna and the personnel 
operating radio equipment. However, RF radiation hazards are not clearly defined from these studies due to a different standard of RF exposure level. The acceptable exposure limits for occupational specified by different standardisation bodies for various frequency ranges summarised in Table 1.

The objective of this study is to describe the measured RF exposure on Armoured Vehicle 8 Wheels (AV8W). The exposure information is then used to approach total exposure and dose assessment. Total RF exposure collected pertaining with the operation tenure of armoured vehicle crew and the transmitting patterns. The dose assessment calculated for daily and annual RF dose for the exposed armoured crew on AV8W. The scope of this paper bounding into selected armoured vehicle crew working station with ordinary operational conditions and uniform transmitting patterns of HF and VHF.

Table 1. A summary of exposure limits.

\begin{tabular}{|c|c|c|c|c|}
\hline Body & Metric & Frequency & $\begin{array}{c}\text { Occupational } \\
\text { values }\end{array}$ & Remarks \\
\hline \multirow{2}{*}{$\begin{array}{l}\text { Military } \\
\text { Standard } \\
464 C\end{array}$} & \multirow{2}{*}{$\begin{array}{l}\text { Electric Field } \\
\text { Strength }\end{array}$} & $2 \mathrm{MHz}-30 \mathrm{MHz}$ & $103 \mathrm{~V} / \mathrm{m}$ & $\mathrm{HF}$ \\
\hline & & $30 \mathrm{MHz}-150 \mathrm{MHz}$ & $74 \mathrm{~V} / \mathrm{m}$ & VHF \\
\hline \multirow{4}{*}{ ICNIRP } & \multirow{2}{*}{$\begin{array}{l}\text { Electric Field } \\
\text { Strength }\end{array}$} & \multirow{2}{*}{$\begin{array}{c}1 \mathrm{MHz}-10 \mathrm{MHz} \\
10 \mathrm{MHz}-400 \\
\mathrm{MHz}\end{array}$} & $610 / f \mathrm{~V} / \mathrm{m}$ & $\mathrm{HF}$ \\
\hline & & & $61 \mathrm{~V} / \mathrm{m}$ & $\mathrm{HF} / \mathrm{VHF}$ \\
\hline & \multirow{2}{*}{$\begin{array}{l}\text { Magnetic Field } \\
\text { Strength }\end{array}$} & \multirow{2}{*}{$\begin{array}{c}1 \mathrm{MHz}-10 \mathrm{MHz} \\
10 \mathrm{MHz}-400 \\
\mathrm{MHz}\end{array}$} & $1.6 / \mathrm{f} \mathrm{A} / \mathrm{m}$ & $\mathrm{HF}$ \\
\hline & & & $0.16 \mathrm{~A} / \mathrm{m}$ & $\mathrm{HF} / \mathrm{VHF}$ \\
\hline \multirow{4}{*}{$\begin{array}{l}\text { IEEE } \\
\text { Standard } \\
95.1- \\
2345-2014\end{array}$} & \multirow{2}{*}{$\begin{array}{l}\text { Electric Field } \\
\text { Strength }\end{array}$} & \multirow{2}{*}{$\begin{array}{c}1 \mathrm{MHz}-30 \mathrm{MHz} \\
30 \mathrm{MHz}-100 \\
\mathrm{MHz}\end{array}$} & $1842 / \mathrm{f} \mathrm{V} / \mathrm{m}$ & $\mathrm{HF}$ \\
\hline & & & $61.4 \mathrm{~V} / \mathrm{m}$ & VHF \\
\hline & \multirow{2}{*}{$\begin{array}{l}\text { Magnetic Field } \\
\text { Strength }\end{array}$} & $1 \mathrm{MHz}-30 \mathrm{MHz}$ & $16.3 / \mathrm{f} \mathrm{A} / \mathrm{m}$ & $\mathrm{HF}$ \\
\hline & & $\begin{array}{c}30 \mathrm{MHz}-100 \\
\mathrm{MHz}\end{array}$ & $0.163 \mathrm{~A} / \mathrm{m}$ & VHF \\
\hline
\end{tabular}

\section{MATERIALS AND METHODS}

The measurement on RF radiation hazard from communication equipment mounted on Armoured Vehicle 8 Wheels (AV8W) has been done concerning the advice from Malaysian Army and Science \& Technology Research Institute for Defence (STRIDE) to provide a safe working environment. In this study, Military Standard 464C [2] and IEEE Standard for Military Workplaces [3] are used where both of these standards protect military personnel against the exposure to electromagnetic fields in the various frequency ranges, between $0.01 \mathrm{MHz}$ to $18 \mathrm{GHz}$ and $0 \mathrm{~Hz}$ to $300 \mathrm{GHz}$ respectively. For critical crew locations located in the near-field region, the International Commission on Non-Ionising Radiation Protection (ICNIRP) guidelines [4] for E-Field and H-Field measurement has been used as the main references standards guidelines.

\section{Description of Armoured Vehicle 8 Wheels (AV8W)}

The AV8W multirole combat vehicles in various configurations have been operative since 2014 by Malaysian Army. Designed with a length of $8 \mathrm{~m}$, width $3 \mathrm{~m}$, weight up to 30 
tonnes and crew consisted of 8 personnel able to perform modern military operational requirements in any nature of the conflict.

Each of these vehicles is equipped with HF and VHF radio sets where the antennas of these sets are mounted on the turret as shown in Figure 1(a). In this study, only two AV8W locations measurements had taken place, namely commander and gunner due to its locations close to both antennas - the measurement took place with three conditions; close hatch, open hatch and standing crew open hatch as illustrated in Figure 1(a) to Figure 1(c).

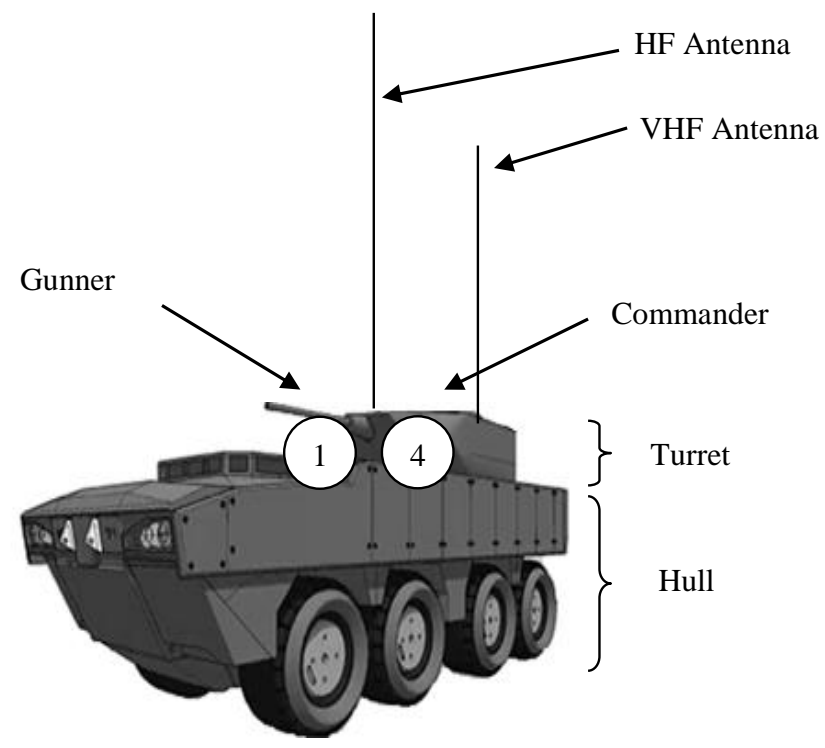

(a) AV8W close hatch condition with measurement spots (1 and 4).

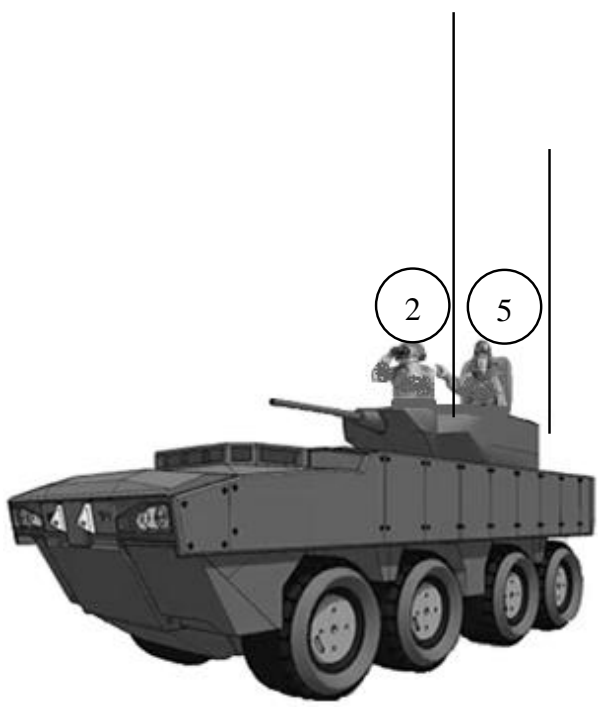

(b)AV8W open hatch condition with measurement spots (2 and 5). 


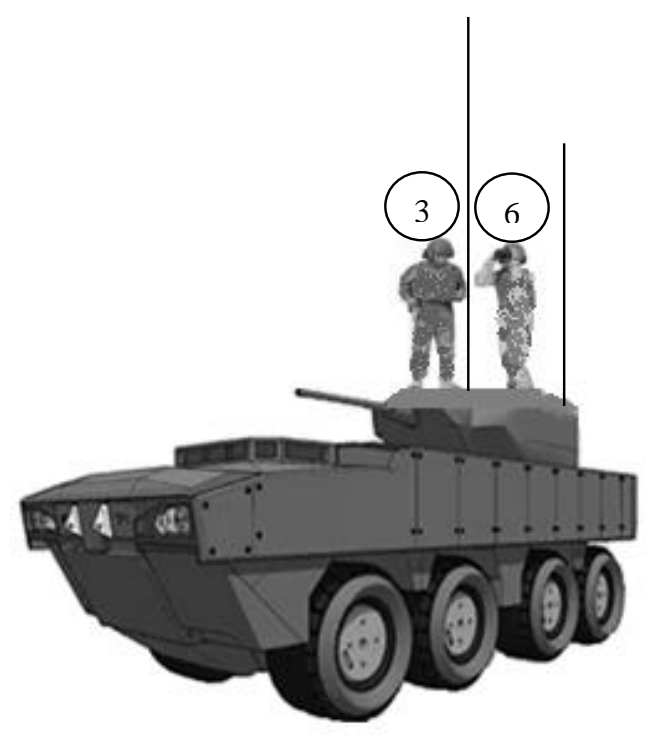

(c) AV8W standing crew open hatch condition with measurement spots (3 and 6).

Figure 1. AV8W multirole combat vehicles in various configurations.

\section{High Frequency (HF) and Very High Frequency (VHF) Antenna}

$\mathrm{RF}$ radiations from both antennas were measured at six different spots on AV8W. The measurements were performed at frequency range $5 \mathrm{MHz}-25 \mathrm{MHz}$ for $\mathrm{HF}$ and $30 \mathrm{MHz}-$ $80 \mathrm{MHz}$ for VHF with an increment of $5 \mathrm{MHz}$ and $10 \mathrm{MHz}$ in each step respectively. Both antennas were transmitted with varied transmission time, the highest estimate being $5 \mathrm{~min} / \mathrm{h}$. During the operation or combat environment, both HF and VHF sets are used concurrently. However, for this study, RF radiations was measured with only from one antenna at a time in a stationary condition. RF radiations from both antennas were measured at six different spots and conditions as shown in Figure 1. The measurements were performed at a frequency range of $5 \mathrm{MHz}$ to $25 \mathrm{MHz}$ for $\mathrm{HF}$ and $30 \mathrm{MHz}$ to $80 \mathrm{MHz}$ for $\mathrm{VHF}$ in $5 \mathrm{MHz}$ and $10 \mathrm{MHz}$ step respectively. Both antennas transmitted varying transmission times with the highest was $5 \mathrm{~min} / \mathrm{h}$. The transmission power to the HF antenna varied from $1 \mathrm{~W}$ to $125 \mathrm{~W}$ and $0.5 \mathrm{~W}$ to $50 \mathrm{~W}$ to the VHF antenna.

\section{Measurement Device}

Two types of measurement device were used for the measurement. Rohde \& Schwarz (R\&S) FSH8 Spectrum Analyser with TSEMF-B3 Typical Isotropic Antenna used for EField measurement. This device measures any sources in the frequency ranges from 9 $\mathrm{kHz}$ to $8 \mathrm{GHz}$. Narda SRM-3006 was another measurement device used to measure $\mathrm{H}$ Field. This device can detect the magnetic field any frequency ranges from $9 \mathrm{kHz}$ to 6 $\mathrm{GHz}$. Both measurement devices were placed at various spots as shown in Figure 1. The distances from the measurement device to both antennas were either in a horizontal line or if the measurement device was lower than the antenna, the distance was measured in a direct line to the antenna base. The actual distances from both antennas to the measurement spots are shown in Table 2. Distance from both antennas to standing crew 
condition is not given in this study. All measurement devices were calibrated before their use.

Table 2. Distances to the VHF and HF antenna and measurement spots on AV8W.

\begin{tabular}{lcccc}
\hline \multirow{2}{*}{ Location } & \multirow{2}{*}{ Condition } & \multicolumn{2}{c}{ Distance from antenna $(\mathrm{m})$} & \multirow{2}{*}{ Spots Number } \\
& Close hatch & 1.8 & 1.5 & 1 \\
\multirow{3}{*}{ Gunner } & Open hatch & 1.64 & 1.22 & 3 \\
& Standing crew & - & - & 5 \\
\multirow{3}{*}{ Commander } & Close hatch & 1.4 & 1.8 & 2 \\
& Open hatch & 1.28 & 1.6 & 4 \\
& Standing crew & - & - & 6 \\
\hline
\end{tabular}

\section{Exposure Calculation: Linear and Spatial Average}

Linear and spatial average exposure calculation suggested by Baste et al. [5] has been applied in this paper. The measurement spots were grouped to a location on the AV8W as shown in Figure 1(a) to (c). Exposure at each location was calculated as both linear in Eq. (1) and spatial in Eq. (2) Exposure, averaged over the actual number of measurement spots in the specific location. Linear average is calculated related to effects depending on E-Field; the spatial average is used by ICNIRP because of the thermal effects of RF electromagnetic field (EMF).

$$
\begin{aligned}
& \text { E-linear }_{\text {equipment }}=\left(\frac{1}{\text { no.of spots }}\right) \sum E \\
& \text { E-spatial }_{\text {equipment }}=\sqrt{\left(\frac{1}{\text { no.of spots }}\right) \sum E^{2}}
\end{aligned}
$$

\section{Annual Accumulative Dose Assessment}

In this study, deployment of armoured vehicle crews in the United Nation (UN) mission becomes a relevant benchmark to calculate the dose assessment on AV8W. Estimated with eleven months per year active tenure of deployment, two cycles active patrol duty per day ( 2 hours per cycle), three days patrol duty per week and minimum transmission time 10 minutes varied on different spots were considered. Estimated RF exposure duration amongst the armoured vehicle crews summarised in Table 3. In order to make the dose assessment related with a period of deployment, spatial average methods have been applied as shown in Equation 3.

Exposure Dose $=$

$$
\sum_{\text {equipment }}\left(\text { E-spatial }_{\text {equipment }} \times 24 \mathrm{~h} \times \text { transmission time }_{\text {equipment }}\right)
$$

This method calculated exposure dose by multiplying spatial average with transmission time and then summed up over the equipment. Each location was calculated separately. To obtain the annual exposure dose, the value was multiplied with mission 
time, which gives an annual time average dose in $\mathrm{V} \mathrm{h} / \mathrm{m}$. The annual exposure dose is given by exposure dose $\times 365 \times$ (active patrol time/12 months). The calculated result with this method is given in Table 10 .

The similar method applied by Baste et al. [5], takes ICNIRP guidelines consideration and performed a calculation as Equation 4. In this study, the reference level for occupational exposure is $E$ reference value $(\mathrm{HF})=610 /$ frequency and the $E$ reference value $(\mathrm{VHF})=61 \mathrm{~V} / \mathrm{m}$ for frequency range $1-80 \mathrm{MHz}$ [4]. To get an annual indication of dose, these values were multiplied by mission time, where annual exposure dose $($ ICNIRP $)=$ exposure dose $($ ICNIRP $) \times 365 \times($ active patrol time $/ 12$ months $)$, which resulted in annual dose in the proportion of ICNIRP and the result given in Table 10.

Exposure Dose (ICNIRP) $=$

$$
\begin{aligned}
& \sum_{\text {equipment }}\left[\left(\frac{\text { E-Spatial }_{\text {equipment }}}{\text { E-Spatial }}\right)_{\text {reference value (equipment) }}^{2} \times 24 \mathrm{~h} \times\right. \\
& \text { transmission time } \text { equipment }_{]}
\end{aligned}
$$

Table 3. Estimated RF exposure duration time amongst armoured vehicle crews.

\begin{tabular}{lc}
\hline Tenure of deployment & Exposure time (minutes) \\
\hline Daily & 20 \\
Weekly & 60 \\
Monthly & 240 \\
Yearly & 2640 \\
\hline
\end{tabular}

\section{RESULTS AND DISCUSSION}

Results from the E-Field measurements on the gunner and commander location with different spots and frequencies are shown in Table 4 and 5 respectively. For each of the $\mathrm{HF}$ and VHF antenna, the mean exposure (E mean) over the frequency range for each measurement spot was calculated. The measurement from HF in the frequency range of $5-25 \mathrm{MHz}$ with low and high-power transmission resulted in value from 0.005 to 0.69 $\mathrm{V} / \mathrm{m}$. The measurement results from VHF in the frequency range of $30-80 \mathrm{MHz}$ were higher than the HF for most of the spots, varied from 0.005 to $252 \mathrm{~V} / \mathrm{m}$.

The H-Field measurements have been done except for spot no. 3 and 6 , due to measurement device safety precautions. The measurements result varied from $10.02 \times 10^{-}$ ${ }^{6}$ to $23.94 \times 10^{-3} \mathrm{~A} / \mathrm{m}$ and are shown in Table 6 and 7 respectively.

\section{Total Exposure Assessment - HF and VHF Antenna}

As regards to estimating the total amount of exposure from gunner and commander location on AV8W, the summation of exposures was calculated with both linear (from Eq. (1)) and spatial average (from Eq. (2)) as given in Table 8 and 9. The highest value has been found at commander location, where the linear and spatial average was equal to $23.2 \mathrm{~V} / \mathrm{m}$ and $40.18 \mathrm{~V} / \mathrm{m}$ respectively, from low power transmission and high power transmission was equal to $301.7 \mathrm{~V} / \mathrm{m}$ and $521.5 \mathrm{~V} / \mathrm{m}$. The annual exposure dose values at both locations on AV8W as shown in Table 10. 
Table 4. E-field measurements from HF and VHF antenna at gunner spots, transmitted with low and high power on AV8W.

\begin{tabular}{|c|c|c|c|c|c|c|}
\hline \multirow{3}{*}{$\begin{array}{l}\text { Transmission } \\
\mathrm{MHz}\end{array}$} & \multicolumn{6}{|c|}{ E-field measurement at gunner $(\mathrm{V} / \mathrm{m})$} \\
\hline & \multicolumn{3}{|c|}{ HF (Low power) } & \multicolumn{3}{|c|}{ HF (High power) } \\
\hline & Spot 1 & Spot 2 & Spot 3 & Spot 1 & Spot 2 & Spot 3 \\
\hline 5 & 0.006 & 0.01 & 0.62 & 0.006 & 0.02 & 0.46 \\
\hline 10 & 0.007 & 0.02 & 0.66 & 0.005 & 0.03 & 0.67 \\
\hline 15 & 0.005 & 0.04 & 0.53 & 0.005 & 0.04 & 0.70 \\
\hline 20 & 0.006 & 0.04 & 0.36 & 0.005 & 0.03 & 0.11 \\
\hline \multirow[t]{2}{*}{25} & 0.007 & 0.01 & 0.28 & 0.014 & 0.01 & 0.66 \\
\hline & \multicolumn{3}{|c|}{ VHF (Low power) } & \multicolumn{3}{|c|}{ VHF (High power) } \\
\hline 30 & 0.007 & 0.005 & 4.57 & 0.014 & 0.010 & 62.0 \\
\hline 40 & 0.005 & 0.005 & 14.3 & 0.030 & 0.043 & 131 \\
\hline 50 & 0.008 & 0.021 & 6.47 & 0.125 & 0.214 & 147 \\
\hline 60 & 0.009 & 0.026 & 3.83 & 0.063 & 0.193 & 52.1 \\
\hline 70 & 0.007 & 0.008 & 8.03 & 0.080 & 0.088 & 94.7 \\
\hline 80 & 0.007 & 0.022 & 5.50 & 0.070 & 0.073 & 75.5 \\
\hline E mean & 0.074 & 0.207 & 45.2 & 0.417 & 0.751 & 565 \\
\hline
\end{tabular}

Table 5. E-field measurements from HF and VHF antenna at commander spots, transmitted with low and high power on AV8W.

\begin{tabular}{|c|c|c|c|c|c|c|}
\hline \multirow{3}{*}{$\begin{array}{l}\text { Transmission } \\
\mathrm{MHz}\end{array}$} & \multicolumn{6}{|c|}{ E-field measurement at commander $(\mathrm{V} / \mathrm{m})$} \\
\hline & \multicolumn{3}{|c|}{ HF (Low power) } & \multicolumn{3}{|c|}{ HF (High power) } \\
\hline & Spot 4 & Spot 5 & Spot 6 & Spot 4 & Spot 5 & Spot 6 \\
\hline 5 & 0.006 & 0.01 & 0.23 & 0.006 & 0.02 & 0.43 \\
\hline 10 & 0.005 & 0.07 & 0.39 & 0.006 & 0.02 & 1.02 \\
\hline 15 & 0.006 & 0.23 & 0.26 & 0.034 & 0.05 & 0.36 \\
\hline 20 & 0.005 & 0.05 & 0.13 & 0.092 & 0.01 & 0.21 \\
\hline \multirow[t]{2}{*}{25} & 0.005 & 0.05 & 0.40 & 0.101 & 0.01 & 0.69 \\
\hline & \multicolumn{3}{|c|}{ VHF (Low power) } & \multicolumn{3}{|c|}{ VHF (High power) } \\
\hline 30 & 0.007 & 0.6 & 6.23 & 0.035 & 8.3 & 78.2 \\
\hline 40 & 0.005 & 1.2 & 21.4 & 0.017 & 16.9 & 246 \\
\hline 50 & 0.010 & 2.3 & 3.10 & 0.053 & 34.9 & 51.7 \\
\hline 60 & 0.018 & 0.9 & 18.8 & 0.108 & 16.2 & 252 \\
\hline 70 & 0.014 & 3.6 & 5.83 & 0.160 & 66.1 & 80.0 \\
\hline 80 & 0.011 & 1.2 & 2.53 & 0.033 & 18.1 & 31.4 \\
\hline E mean & 0.092 & 10.2 & 59.3 & 0.645 & 160 & 742 \\
\hline
\end{tabular}


Table 6. H-field measurements from HF and VHF antenna at gunner spots, transmitted with low and high power on AV8W.

\begin{tabular}{|c|c|c|c|c|c|c|}
\hline \multirow{3}{*}{$\begin{array}{l}\text { Transmission } \\
\mathrm{MHz}\end{array}$} & \multicolumn{6}{|c|}{ H-field measurement at gunner $(\mathrm{A} / \mathrm{m})$} \\
\hline & \multicolumn{3}{|c|}{ HF (Low power) } & \multicolumn{3}{|c|}{ HF (High power) } \\
\hline & $\begin{array}{l}\text { Spot 1 } \\
\left(\times 10^{-3}\right)\end{array}$ & $\begin{array}{l}\text { Spot 2 } \\
\left(\times 10^{-3}\right)\end{array}$ & Spot 3 & $\begin{array}{l}\text { Spot 1 } \\
\left(\times 10^{-3}\right)\end{array}$ & $\begin{array}{l}\text { Spot 2 } \\
\left(\times 10^{-3}\right)\end{array}$ & Spot 3 \\
\hline 5 & 0.16 & 0.83 & - & 0.18 & 0.69 & - \\
\hline 10 & 0.15 & 0.59 & - & 0.83 & 0.46 & - \\
\hline 15 & 0.07 & 0.26 & - & 0.07 & 0.32 & - \\
\hline 20 & 0.05 & 0.19 & - & 0.07 & 0.28 & - \\
\hline \multirow[t]{2}{*}{25} & 0.06 & 0.15 & - & 0.06 & 0.25 & - \\
\hline & \multicolumn{2}{|c|}{ VHF (Low power) } & \multicolumn{4}{|c|}{ VHF (High power) } \\
\hline 30 & 0.52 & 2 & - & 6.9 & 19.65 & - \\
\hline 40 & 0.62 & 2.37 & - & 8.52 & 22.39 & - \\
\hline 50 & 0.63 & 3.3 & - & 9.41 & 24.79 & - \\
\hline 60 & 0.43 & 2.74 & - & 7.02 & 25.8 & - \\
\hline 70 & 0.32 & 1.75 & - & 4.29 & 20.46 & - \\
\hline 80 & 0.22 & 1.38 & - & 3.14 & 17.29 & - \\
\hline H mean & 3.23 & 15.56 & - & 40.49 & 132.38 & - \\
\hline
\end{tabular}

Table 7. H-field measurements from HF and VHF antenna at commander spots, transmitted with low and high power on AV8W.

\begin{tabular}{|c|c|c|c|c|c|c|}
\hline \multirow{3}{*}{$\begin{array}{l}\text { Transmission } \\
\mathrm{MHz}\end{array}$} & \multicolumn{6}{|c|}{ H-field measurement at commander $(\mathrm{A} / \mathrm{m})$} \\
\hline & \multicolumn{3}{|c|}{ HF (Low power) } & \multicolumn{3}{|c|}{ HF (High power) } \\
\hline & $\begin{array}{l}\text { Spot } 4 \\
\left(\times 10^{-6}\right)\end{array}$ & $\begin{array}{l}\text { Spot 5 } \\
\left(\times 10^{-3}\right)\end{array}$ & Spot 6 & $\begin{array}{l}\text { Spot } 4 \\
\left(\times 10^{-6}\right)\end{array}$ & $\begin{array}{l}\text { Spot 5 } \\
\left(\times 10^{-3}\right)\end{array}$ & Spot 6 \\
\hline 5 & 30.35 & 0.35 & - & 32.7 & 0.311 & - \\
\hline 10 & 14.64 & 0.33 & - & 14.4 & 0.218 & - \\
\hline 15 & 9.30 & 1.36 & - & 8.2 & 1.372 & - \\
\hline 20 & 10.02 & 0.41 & - & 13.0 & 0.323 & - \\
\hline \multirow[t]{2}{*}{25} & 6.46 & 0.11 & - & 8.8 & 0.177 & - \\
\hline & \multicolumn{3}{|c|}{ VHF (Low power) } & \multicolumn{3}{|c|}{ VHF (High power) } \\
\hline 30 & 21.50 & 2.48 & - & 683.5 & 20.65 & - \\
\hline 40 & 19.35 & 3.36 & - & 2610.3 & 22.127 & - \\
\hline 50 & 54.59 & 4.69 & - & 742.9 & 23.943 & - \\
\hline 60 & 36.34 & 2.72 & - & 1435.9 & 23.427 & - \\
\hline 70 & 32.95 & 2.63 & - & 992.8 & 21.067 & - \\
\hline 80 & 159.14 & 1.53 & - & 2823.3 & 19.46 & - \\
\hline $\mathrm{H}$ mean & 394.64 & 19.97 & - & 9365.8 & 133.08 & - \\
\hline
\end{tabular}


Table 8. Exposure calculation: linear and spatial average for HF and VHF low power transmission at gunner and commander location on AV8W.

\begin{tabular}{lcccc|cccc}
\hline Range & $\begin{array}{c}\text { Linear* } \\
(\mathrm{V} / \mathrm{m})\end{array}$ & $\begin{array}{c}\text { Linear\# } \\
(\mathrm{V} / \mathrm{m})\end{array}$ & $\begin{array}{c}\text { Spatial* } \\
(\mathrm{V} / \mathrm{m})\end{array}$ & $\begin{array}{c}\text { Spatial\# } \\
(\mathrm{V} / \mathrm{m})\end{array}$ & $\begin{array}{c}\text { Linear* } \\
(\mathrm{V} / \mathrm{m})\end{array}$ & $\begin{array}{c}\text { Linear\# } \\
(\mathrm{V} / \mathrm{m})\end{array}$ & $\begin{array}{c}\text { Spatial* } \\
(\mathrm{V} / \mathrm{m})\end{array}$ & $\begin{array}{c}\text { Spatial\# } \\
(\mathrm{V} / \mathrm{m})\end{array}$ \\
\hline HF & 0.87 & 0.075 & 1.5 & 0.106 & 0.62 & 0.22 & 1.07 & 0.31 \\
\hline VHF & 14.27 & 0.065 & 24.7 & 0.091 & 22.59 & 4.93 & 39.12 & 6.98 \\
\hline $\begin{array}{l}\text { Total } \\
\text { Exposure }\end{array}$ & 15.14 & 0.141 & 26.3 & 0.197 & 23.2 & 5.15 & 40.18 & 7.29 \\
\hline
\end{tabular}

*All spots \#Exclude spot no. 3 and 6

Table 9. Exposure calculation: Linear and spatial average for HF and VHF high power transmission at gunner and commander location on AV8W.

\begin{tabular}{lcccc|cccc}
\hline \multirow{2}{*}{ Range } & $\begin{array}{c}\text { Linear* } \\
(\mathrm{V} / \mathrm{m})\end{array}$ & $\begin{array}{c}\text { Linear\# } \\
(\mathrm{V} / \mathrm{m})\end{array}$ & $\begin{array}{c}\text { Spatial* } \\
(\mathrm{V} / \mathrm{m})\end{array}$ & $\begin{array}{c}\text { Spatial\# } \\
(\mathrm{V} / \mathrm{m})\end{array}$ & $\begin{array}{c}\text { Linear* } \\
(\mathrm{V} / \mathrm{m})\end{array}$ & $\begin{array}{c}\text { Commander } \\
(\mathrm{V} / \mathrm{m})\end{array}$ & $\begin{array}{c}\text { Spatial* } \\
(\mathrm{V} / \mathrm{m})\end{array}$ & $\begin{array}{c}\text { Spatial\# } \\
(\mathrm{V} / \mathrm{m})\end{array}$ \\
\hline $\mathrm{HF}$ & 0.92 & 0.08 & 1.6 & 0.12 & 1.01 & 0.17 & 1.77 & 0.25 \\
VHF & 187.77 & 0.5 & 325.22 & 0.71 & 300.06 & 80.45 & 519.73 & 113.8 \\
Total & 188.69 & 0.58 & 326.82 & 0.83 & 301.07 & 80.62 & 521.5 & 114.05 \\
Exposure & & & & & & &
\end{tabular}

*All spots \#Exclude spot no. 3 and 6

Table 10. HF and VHF antenna with annual exposure dose values at gunner and commander location on AV8W.

\begin{tabular}{lcccc}
\hline \multirow{2}{*}{$\begin{array}{l}\text { Location } \\
\text { Spots }\end{array}$} & Low Power & High Power & Low Power & High Power \\
\hline $\begin{array}{l}\text { All spots } \\
\begin{array}{l}\text { Exclude } \\
\text { spot no.3 }\end{array}\end{array}$ & $202 \times 10^{6}$ & $2519 \times 10^{6}$ & $309 \times 10^{6}$ & $4020 \times 10^{6}$ \\
and 6 & $1.5 \times 10^{6}$ & $6 \times 10^{6}$ & $56 \times 10^{6}$ & $879 \times 10^{6}$ \\
\hline & $\begin{array}{c}\text { ICNIRP- Low } \\
\text { Power }\end{array}$ & $\begin{array}{c}\text { ICNIRP- High } \\
\text { Power }\end{array}$ & $\begin{array}{c}\text { ICNIRP- Low } \\
\text { Power }\end{array}$ & $\begin{array}{c}\text { ICNIRP- High } \\
\text { Power }\end{array}$ \\
$\begin{array}{l}\text { All spots } \\
\begin{array}{l}\text { Exclude } \\
\text { spot no.3 } \\
\text { and 6 }\end{array}\end{array}$ & $693 \times 10^{3}$ & $110 \times 10^{6}$ & $1622 \times 10^{3}$ & $280 \times 10^{6}$ \\
\hline
\end{tabular}

RF radiation dose assessment methods creating new challenge to armoured vehicle RF radiation exposure study due to various factors which may probably affect the results. In a study carried out by Baste et al. [5] recorded RF radiation exposure ranges $5.5 \times 10^{3} \mathrm{~V} \mathrm{~h} / \mathrm{m}$ to $152 \times 10^{3} \mathrm{~V} \mathrm{~h} / \mathrm{m}$ as a result from calculated annual ship dose on the different locations and tenure of sailing. This study was similar to the methods of calculating continuous RF radiation hazard onto crew onboard of a ship which was based on annual mission time for different periods and dose on different locations within the ship. 
The measurements were made in near-field region and changes in distance to the RF source can affect the values of both E Field and $\mathrm{H}$ Field, required investigation both fields are taken into account $[4,9]$. However, not all conditions have measured H-Field due to device restriction. Thus the relative connection between E-Field and H-Field in exposure near field is not achievable.

In this study, the values measured from both antennas during the open and close hatch condition complied with the ICNIRP and others standard guidelines. However, some values are exceeding the limits; especially on commander standing crew open hatch condition with the highest value of $742 \mathrm{~V} / \mathrm{m}$. As a result, this value contributing the most extreme RF radiation exposure level. The higher E-Field value probably influenced by the factors such as the antennas distances to personnel position, vehicle dimensions, windows, material, and ground surrounding [6,7]. Others study on military vehicle RF radiation levels carried out by Alcaras and Frere [8] shown the E-Field results range 1200 $\mathrm{V} / \mathrm{m}$ from the $125 \mathrm{~W}$ HF transmission and $200 \mathrm{~V} / \mathrm{m}$ from $50 \mathrm{~W}$ VHF transmission respectively. The RF radiations levels were measured $1 \mathrm{~m}$ from both antennas.

Summation values of exposure, HF and VHF seemed realistic with these methods due to the condition of the crew and the radio system on AV8W and specified tenure of deployment in the mission. Hence, the RF radiation dose assessment approach probably yielded a satisfactory indication of exposure level.

\section{CONCLUSION}

The measurements and calculated of RF radiation exposure emitted by the HF and VHF antenna aboard AV8W have been performed at a selected location normally occupied by the crew. Various range of RF radiation values from measurement was demonstrated as a result of the different mode of transmission power, the tenure of mission deployment, location and condition of the crews. Hence, dose assessment values significantly influenced by these factors. Since this measurement was conducted in the open area test site, the results may probably influence by man-made surrounding factors. Ideal and absorbance measurement place need consider in further research of armoured vehicle development for more accuracy of RF radiation exposure result.

\section{REFERENCES}

[1] World Health Organization (WHO). Establishing a dialogue on risks from electromagnetic fields. Retrieved from http://www.who.int/pehemf/publication/en/EMF_Risk_ALL.pdf; 20 July, 2018.

[2] Military Standard 464C. Electromagnetic environmental effects requirements for systems. Department of Defense, United States of America. Retrieved from https://novaintegration.com/wp-content/uploads/2015/11/MIL-STD-464C.pdf; 5 July, 2018.

[3] The Institute of Electrical and Electronics Engineers (IEEE). Standard for military workplaces-force health protection regarding personnel exposure to electric, magnetic, and electromagnetic fields, $0 \mathrm{~Hz}$ to $300 \mathrm{GHz}$. IEEE Standard 95.1-2345. Retrieved from https://ieeexplore.ieee.org/document/6766647; 20 August, 2018.

[4] International Commission on Non-Ionizing Radiation Protection (ICNIRP). Guidelines for limiting exposure to time-varying electric, magnetic, and electromagnetic fields (up to $300 \mathrm{GHz}$ ). Retrieved from https://www.icnirp.org; 24 August, 2018. 
[5] Baste V, Mild K, Moen B. Radiofrequency exposure on fast patrol boats in the Royal Norwegian Navy - an approach to a dose assessment. Bioelectromagnetics. 2010; 31: 350-360.

[6] Sobiech J, Kieliszek J, Puta R, Bartczak D, Stankiewicz W. Occupational exposure to electromagnetic fields in the Polish armed forces. International Journal of Occupational Medicine and Environmental Health. 2017; 30(4): 565577.

[7] Lopez DG, Ignatenko M, Filipovic DS. RF exposure inside and outside vehicles. In: IEEE Antennas and Propagation Society International Symposium, Memphis, USA, pp. 607-608; 2014.

[8] Alcaras A, Frere J. Thermal risks due to land vehicle radioelectric exposure. Results of Thales research and study for military purpose. In: International Symposium on Electromagnetic Compatibility-EMC EUROPE 2017, Angers, France; 4-8 September, 2017.

[9] Annamaria P, Simona M. Near field level emitted by professional radio communication devices: preliminary measurements and simulations for an occupational exposure assessment approach. In: International Conference and Exposition on Electrical and Power Engineering, Iasi, Romania; 16-18 October, 2014.

[10] Karpowicz J, Bienkowski P, Kieliszek J. Model of the minimum requirements regarding electric and magnetic field strength measurement devices for use in the near-field occupational exposure in compliance testing with respect to the requirements of European Directive 2013/35/EU. In: International Symposium on Electromagnetic Compatibility-EMC EUROPE 2016, Wroclaw, Poland, pp. 668$671 ; 2016$.

[11] Coulombe M, Deschênes P, Pinchuk R, Paknys R. Electromagnetic environmental effects (E3) computational analysis of a navy frigate. In: IEEE International Symposium on Electromagnetic Compatibility, Pittsburgh, USA, pp. 261-266; 2012.

[12] Malka N, Halgamuge. Radio hazard safety assessment for marine ship transmitters: measurements using a new data collection method and comparison with ICNIRP and ARPANSA limits. International Journal Environment Research and Public Health. 2015; 12: 5338-5354.

[13] Ole J, Bente E. Is fertility reduced among men exposed to radiofrequency fields in the Norwegian Navy. Bioelectromagnetics. 2008; 29: 345-352.

[14] Joseph W, Goeminne F, Verloock L, Vermeeren G, Martens L. In-situ occupational and general public exposure to $\mathrm{VHF} / \mathrm{UHF}$ transmission for air traffic communication. Radiation Protection Dosimetry. 2012; 151(3): 411-419.

[15] Buckus R, Strukcinskiene B, Raistenskis J, Stukas R, Šidlauskiene A, Cerkauskien R, Isopescu DN, Stabryla J, Cretescu I. A technical approach to the evaluation of radiofrequency radiation emissions from mobile telephony base stations. International Journal Environment Research and Public Health. 2017; 14: 244.

[16] Marin G, Samoilescu G, Baciu A, Iorgulescu D, Radu S. Assessment of the need for protection against electromagnetic radiation of personnel onboard warships. In: International Conference on Advancements of Medicine and Health Care through Technology, Cluj Napona, Romania; 5-7 June, 2014. 
[17] Moen BE, Mollerlokken OJ, Bull N, Oftedal G, Mild KH. Accidental exposure to electromagnetic fields from the radar of a naval ship: a descriptive study. International Maritime Health Journal. 2013; 64(4): 177-182.

[18] Preece AW, Georgiou AG, Dunn EJ, Farrow SC. Health response of two communities to military antennae in Cyprus. Journal of Occupational and Environmental Medicine. 2007; 64(6): 402-408.

[19] Lopez DG, Ignatenko M, Filipovic DS. Eigenmode prediction of high RF exposure frequency region inside vehicles. IEEE Transactions on Electromagnetic Compatibility. 2017; 59(1): 43-47.

[20] Alcaras A. EMC performances of a land army vehicle to respect integrated radios reception sensitivity: Typical performances needed for fitted for radio (FFR) land vehicle. In: International Symposium on Electromagnetic Compatibility-EMC Europe 2018, Amsterdam, Netherlands; 27-30 August, 2018. 